\title{
Remisi dalam Tindak Pidana Pembunuhan (Studi Perbandingan Hukum Pidana Islam dan Hukum Pidana Nasional)
}

\author{
Rahmatiah HL \\ rahmatiah.rahmatiah69@gmail.com \\ Universitas Islam Negeri Alauddin Makassar
}

\begin{abstract}
الملخص
وتحلل هذه الدراسة كيفية تخفيف الأحكام في الفقه الجنائى الإسلامى والقانون

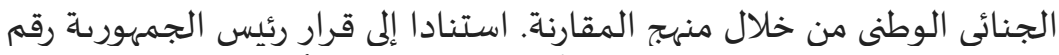

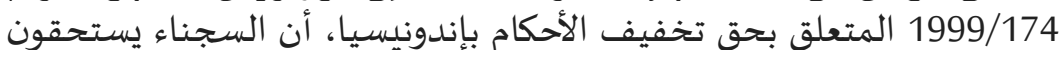

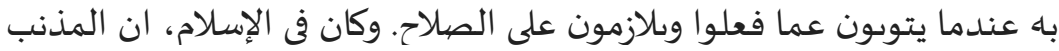

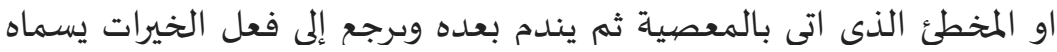

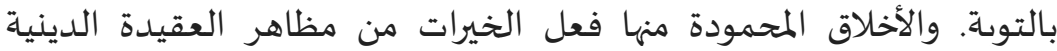

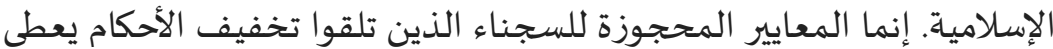

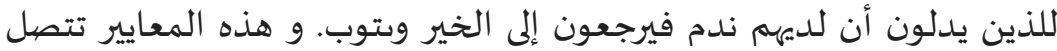

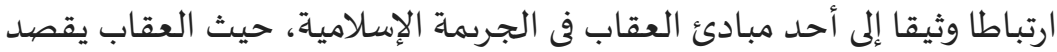

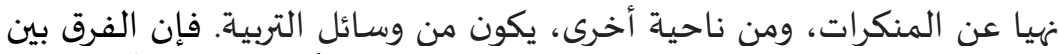

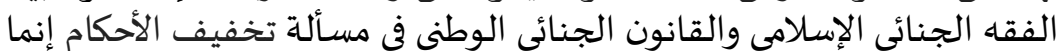

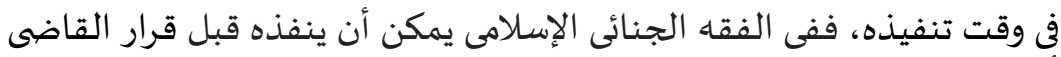

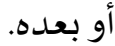

الكلمات الدالة: تخفيف الأحكام، الفقه الجنائى الإسلامى، القانون الجنائى الجئي

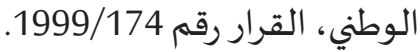

\begin{abstract}
This study analyzes the remission of Islamic criminal law and national criminal law by comparative method. Based on Presidential Decree No. $174 / 1999$ on the right to remission in Indonesia is reserved for prisoners who meet the conditions of goodness in the sense of repenting. In the teachings of Islam, bad behavior that already done will cause a sense of regret and doing good things immediately. Such attitude is known as repented (Arabic: taubah). Good behavior is a manifestation of religious belief and devotion. The criteria reserved for prisoners who received remission gave the view that the prisoner had a sense of regret and repentance. The criteria are also generally in line and closely related to one of the principles of punishment in Islamic crime, where punishment is as well as the media of teaching and learning. The difference lies in the timing of remission in Islamic criminal law can be given before or after the judge's verdict (verdict).
\end{abstract}


Keywords: Remission, Islamic Criminal Law, National criminal law

\begin{abstract}
Abstrak
Penelitian ini menganalisa pemberian remisi dalam hukum pidana Islam dan hukum pidana nasional dengan metode komparasi. Berdasarkan Keputusan Presiden Republik Indonesia Nomor 174 Tahun 1999 tentang hak atas remisi di Indonesia diperuntukkan bagi narapidana yang memenuhi syarat-syarat menuju kebaikan dalam arti bertaubat. Dalam ajaran Islam, Kelakuan buruk yang terlanjur dilakukan akan menimbulkan rasa penyesalan dan segera berbuat baik. Sikap yang demikian dikenal dengan istilah taubat. Kelakuan baik merupakan manifestasi dari keyakinan dan ketaatan dalam beragama (berislam). Kriteria yang diperuntukkan bagi narapidana yang mendapatkan remisi memberi pandangan bahwa narapidana tersebut ada rasa penyesalan dan indikasi bertaubat. Kriteria tersebut juga secara umum sejalan dan erat hubungannya dengan salah satu prinsip hukuman dalam pidana Islam yang bertujuan untuk pencegahan terjadinya kejahatan dan sekaligus sebagai media pembelajaran. Perbedaannya terletak pada waktu pemberian remisi dalam hukum pidana Islam dapat diberikan sebelum atau sesudah putusan hakim (vonis).
\end{abstract}

Kata kunci: Remisi, Hukum Pidana Islam, Hukum pidana nasional

\title{
A. Latar Belakang Masalah
}

Negara Indonesia berdasarkan atas hukum (Rechtstaat), tidak berdasarkan atas kekuasaan belaka (Machstaat), hal tersebut ditegaskan dalam pasal 1 ayat 3 UndangUndang Dasar Negara RI Tahun 1945. Hal ini berarti bahwa Republik Indonesia adalah negara hukum yang demokratis berdasarkan Pancasila dan UUD NRI Tahun 1945, menjunjung tinggi Hak Asasi Manusia, dan menjamin semua warga negara mempunyai kedudukan yang sama di dalam hukum. Hukum menetapkan apa yang harus dilakukan dan apa saja yang tidak boleh dilakukan. Sasaran hukum yang hendak dituju bukan saja orang yang nyata-nyata berbuat melawan hukum, melainkan perbuatan yang mungkin akan terjadi, dan kepada alat perlengkapan negara untuk bertindak menurut hukum. Sistem bekerjanya hukum yang demikian ini merupakan salah satu bentuk penegakan hukum.

Kejahatan yang semakin meningkat dan sering terjadi dalam masyarakat merupakan permasalahan yang perlu diperhatikan, sehingga mengundang pemerintah (negara) sebagai pelayan, pelindung masyarakat untuk menanggulangi meluasnya dan bertambahnya kejahatan yang melanggar nilai-nilai maupun norma-norma yang hidup 
dan berlaku di dalam suatu masyarakat sehingga kejahatan tersebut oleh negara dijadikan sebagai perbuatan pidana untuk tindak pidana. ${ }^{1}$

Hukum pidana merupakan sarana yang penting dalam penanggulangan kejahatan atau mungkin sebagai obat dalam memberantas kejahatan yang meresahkan dan merugikan masyarakat pada umumnya dan korban pada khususnya. Penanggulangan kejahatan tersebut dapat dilakukan secara preventif (pencegahan) dan represif (penindakan). ${ }^{2}$ Bentuk penanggulangan tersebut dengan diterapkannya sanksi terhadap pelaku tindak pidana, sanksi pidana merupakan alat atau sarana terbaik yang tersedia, yang dipakai untuk menghadapi ancaman-ancaman dan bahaya. Sanksi pidana suatu ketika merupakan penjamin yang utama atau terbaik dan suatu etika merupakan pengancaman yang utama dan kebebasan manusia.

Sedangkan di dalam Islam, hukum pidana Islam merupakan terjemahan dari kata fiqh jinayah yaitu segala ketentuan hukum mengenai tindak pidana atau perbuatan kriminal yang dilakukan oleh orang-orang mukalaf (orang yang dapat dibebani kewajiban), sebagai hasil dari pemahaman atas dalil-dalil hukum yang terperinci dari al-Qur'an dan Hadis. ${ }^{3}$

Tujuan hukum adalah untuk mewujudkan tata kehidupan negara yang aman, tentram, aman sejahtera, dan tertib dimana kedudukan hukum setiap warga negaranya dijamin sehingga bisa tercapainya sebuah keserasian, keseimbangan dan keselarasan antara kepentingan perorangan maupun kepentingan kelompok (masyarkat). Konsep negara hukum pancasila artinya suatu sistem hukum yang didirikan berdasarkan asasasas dan kaidah atau norma-norma yang terkandung/tercermin dari nilai yang ada dalam pancasila sebagai dasar kehidupan bermasyarakat. Sejalan dengan tujuan hukum menurut paham konvensional adalah: semata-mata hanya untuk mewujudkan keadilan (justice), kemanfaatan (utility), dan untuk mewujudkan kepastian hokum (legal certainty), bahkan teori hukum Barat lebih berorientasi pada tujuan hukum yaitu keadilan, kemanfaatan dan kepastian hukum. Oleh karenanya putusan hakim harus berdasarkan keadilan. ${ }^{4}$

Kitab Undang-Undang Hukum Pidana (KUHP) dan hukum pidana Islam, tindak pidana mempunyai macam-macam bentuknya, ancaman hukuman yang diberikanpun berbeda antar satu tindak pidana, baik dari pidana yang paling ringan maupun yang terberat sekalipun, Salah satu contohnya adalah tindak pidana pembunuhan.

Kitab Undang-Undang Hukum Pidana (KUHP) hukuman bagi tindak pidana pembunuhanpun berbeda antara pasal satu dengan pasal yang lain, seperti halnya dalam Pasal 338 KUHP disebutkan "Barang siapa dengan sengaja merampas nyawa orang lain diancam karena pembunuhan dengan pidana penjara paling lama lima belas tahun penjara", 5 tetapi akan berbeda pula hukumannya jika pembunuhan itu didahului dengan perencanaan seperti dalam Pasal 339 yang diancam dengan hukuman seumur hidup.

Hukum pidana nasional di Indonesia mengatur jenis-jenis sanksi yang diterapkan kepada pelaku tindak pidana dapat dilihat dalam Pasal 10 KUHP yaitu:

1. Hukuman pokok, yang terdiri dan: hukuman mati, hukuman pidana,hukuman kurungan, dan hukuman denda. 
2. Hukuman-hukuman tambahan, yang terdiri pencabutan beberapa hak tertentu, perampasan barang yang tertentu, dan pengumuman keputusan hakim. ${ }^{6}$

Sedangkan di dalam hukum pidana Islam jenis hukuman dibedakan menjadi dua yaitu (a) ketentuan hukuman yang pasti mengenai berat ringannya hukuman termasuk kisas dan diat yang tercantum didalam al-Qur'an dan hadis. Hal dimaksud adalah hudud, (b) ketentuan hukuman yang dibuat oleh hakim melalui putusannya yang disebut hukuman takzir. Jarimah Hudud adalah perbuatan pidana yang mempunyai bentuk dan batas hukumannya dalam al-Qur'an dan sunnah Nabi Muhammad saw. Sedangkan Jarimah Takzir adalah perbuatan pidana yang bentuk dan ancaman hukumannya ditentukan oleh penguasa (hakim) sebagi pelajaran kepada pelakunya. ${ }^{7}$ Pembunuhan termasuk jarimah atau tindak pidana yang diancam hukuman kisas.

Hukum pidana Islam pembunuhan dikelompokkan menjadi tiga yaitu pembunuhan sengaja, pembunuhan tidak sengaja, dan pembunuhan semi sengaja. Hukum pidana Islam menjatuhkan sanksi pidana yang sangat berat bagi pelaku pembunuhan yang disengaja yaitu dengan tindakan hukuman pidana mati atau hukuman Kisas. Namun, pelaksanaan hukuman itu diserahkan pada putusan keluarga si terbunuh, pilihannya apakah tetap dilaksanakan hukuman Kisas atau dimaafkan dengan penggantian berupa diat atau denda sebesar yang ditetapkan oleh keluarga si terbunuh. Meskipun keputusan diserahkan kepada keluarga si terbunuh, tapi adanya hukuman Kisas ini ternyata efektif untuk meminimalisir terjadinya pembunuhan nyawa orang yang tidak bersalah. ${ }^{8}$

Hal ini sesuai dengan firman Allah swt. dalam QS al-Baqarah/2: 178

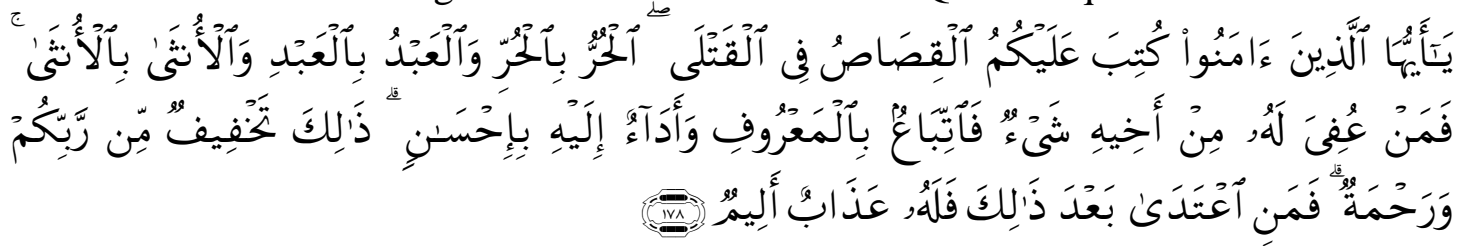

Terjemahnya:

"Hai orang-orang yang beriman, diwajibkan atas kamu Kisas berkenaan dengan orang-orang yang dibunuh; orang merdeka dengan orang merdeka, hamba dengan hamba, dan wanita dengan wanita. Maka Barangsiapa yang mendapat suatu pema'afan dari saudaranya, hendaklah (yang memaafkan) mengikuti dengan cara yang baik, dan hendaklah (yang diberi maaf) membayar (diyat) kepada yang memberi maaf dengan cara yang baik (pula). yang demikian itu adalah suatu keringanan dari Tuhan kamu dan suatu rahmat. Barangsiapa yang melampaui batas sesudah itu, Maka baginya siksa yang sangat pedih"9

Kisas ialah mengambil pembalasan yang sama. Kisas itu tidak dilakukan, bila yang membunuh mendapat pemaafan dari ahli waris yang terbunuh yaitu dengan membayar diat (ganti rugi) yang wajar. Pembayaran diyat diminta dengan baik, umpamanya dengan tidak mendesak yang membunuh, dan yang membunuh 
hendaklah membayarnya dengan baik, umpamanya tidak menangguh-nangguhkannya. Bila ahli waris si korban sesudah Tuhan menjelaskan hukum-hukum ini, membunuh yang bukan si pembunuh, atau membunuh si pembunuh setelah menerima diat, maka terhadapnya di dunia diambil kisas dan di akhirat dia mendapat siksa yang pedih. Jadi Kisas itu berarti memperlakukan seseorang sebagaimana orang itu memperlakukan orang lain.

Hukum pidana Islam juga mengenal dengan adanya gugurnya hukuman karena sebab tertentu. Gugurnya hukuman disini adalah tidak dapat dilaksanakannya hukuman-hukuman yang telah dijatuhkan atau diputuskan oleh hakim, berhubung tempat (badan atau bagiannya) untuk melaksanakan hukuman sudah tidak ada lagi, atau waktu untuk melaksanakannya sudah lewat. Adapun sebab-sebab gugurnya hukuman tersebut salah satunya adalah adanya pengampunan. ${ }^{10}$ Kasus pembunuhan pun, hukum Islam mengenal asas pemaafan sebagaimana yang difirmankan oleh Allah swt. dalam penggalan QS al-Baqarah/2: 178.

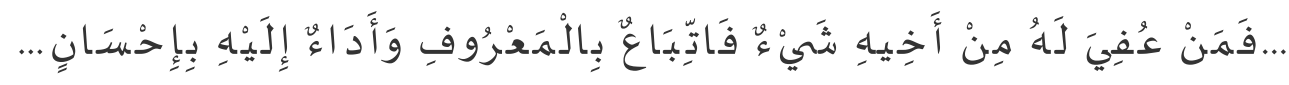

Terjemahnya:

...Maka Barangsiapa yang mendapat suatu pemaafan dari saudaranya, hendaklah (yang memaafkan) mengikuti dengan cara yang baik.. ${ }^{11}$

Pelaksanaan pidana mati dalam sejarah hukum pidana di Indonesia sudah sering terjadi, dengan alasan kemanusiaan hukuman mati sering digantikan dengan hukuman penjara. Hukuman penjara adalah suatu tempat yang khusus dibuat dan digunakan para terhukum dalam menjalankan hukumannya sesuai putusan hakim. ${ }^{12}$ Pidana penjara atau pidana lain yang menghilangkan kemerdekaan bergerak seseorang, pada akhir tujuannya adalah melindungi masyarakat dari segala bentuk kejahatan, jadi apabila negara tidak memberikan hukuman yang tidak setimpal kepada pelaku kejahatan maka negara telah melakukan pelanggaran Hak Asasi Manusia (HAM). Presiden RI melalui Menteri Hukum dan HAM setiap tahun ketika hari-hari besar kenegaraan dan hari besar agama memberikan suatu pengurangan masa tahanan atau yang sering disebut dengan Remisi. Pengertian remisi adalah sebagai pembebasan hukuman untuk seluruhnya atau sebagian atau dari seumur hidup menjadi hukuman terbatas yang diberikan setiap tanggal 17 Agustus. ${ }^{13}$ Sedangkan remisi menurut Kepres RI no. 174 Tahun 1999 tentang remisi adalah pengurangan masa pidana yang diberikan kepada setiap narapidana bila yang bersangkutan berkelakuan baik selama menjalani pidananya. ${ }^{14}$ Dengan demikian maka nararpidana tidak akan menjalankan hukuman yang diberikan secara penuh sehingga dengan adanya remisi ini apakah akan membuat jera bagi pelaku tindak pidana untuk tidak mengulangi perbuatannya lagi atau menjadi residifis.

Kitab Undang-Undang Hukum Pidana (KUHP) dalam penerapannya sudah mulai disesuaikan dengan prinsip keadilan bagi masyarakat Indonesia, tetapi putusan seorang hakim yang mempunyai putusan tetap dapat berubah dan berkurang dengan adanya remisi ini. Pemberian remisi ini tidak melihat dari jenis tindak pidana yang dilakukan, tetapi hanya pada lamanya masa tahanan yang akan dijalani dan 
berperilaku baik selama menjalani hukuman. Seperti pada tindak pidana pembunuhan sekalipun yang tetap mendapat remisi, padahal tindak pidana pembunuhan ini telah nyata merampas hak hidup orang lain. Tentu muncul pertanyaan adilkah remisi ini dilihat dari pihak korban? Tentu ini menjadi persoalan yang tidak hanya dilihat dari satu sudut pandang semata.

Berdasarkan latar belakang di atas, pokok masalah yang akan dibahas adalah bagaimana ketentuan pemberian remisi yang terdapat dalam Keppres RI No. 174 tahun 1999 bagi pelaku tindak pidana pembunuhan? Pokok masalah tersebut akan dianalisis secara kritis dan akan ditinjau dari sudut pandang atau perspektif hukum pidana Islam (Fiqh Jinayah).

\section{B. Pembahasan}

\section{Tinjauan Umum Keppres RI No 174 tahun 1999 tentang Remisi}

Ketentuan mengenai tata cara dan persyaratan pemenuhan hak pengurangan masa pidana ini, dapat dilihat pada Keputusan Presiden Republik Indonesia Nomor 174 Tahun 1999 Tentang Remisi. Setiap narapidana dan anak pidana yang menjalani pidana penjara sementara dan pidana kurungan dapat diberikan remisi dengan adil tanpa adanya diskriminasi yang didasarkan oleh faktor sosial, budaya dan ekonomi apabila yang bersangkutan baik selama menjalani pidana.

Kementerian Hukum dan HAM sebagai sistem pemasyarakatan Indonesia, menyelenggarakan sistem pemasyarakatan agar narapidana dapat memperbaiki diri dan tidak mengulangi tindak pidana, sehingga narapidana dapat diterima kembali dalam lingkungan masyarakatnya, kembali aktif berperan dalam pembangunan serta hidup secara wajar sebagai seorang warga negara. Saat seorang narapidana menjalani vonis yang dijatuhkan oleh pengadilan, maka hak-haknya sebagai warga negara akan dibatasi. Sesuai UU.No.12 Tahun 1995 tentang Pemasyarakatan, bahwa Narapidana adalah terpidana yang menjalani pidana hilang kemerdekaan di Lembaga Pemasyarakatan sedangkan Anak Pidana adalah anak yang berdasarkan putusan pengadilan menjalani pidana di LAPAS anak paling lama sampai berumur 18 (delapan belas) tahun. Walaupun terpidana kehilangan kemerdekaannya, tapi ada hakhak narapidana yang tetap dilindungi dalam sistem pemasyarakatan Indonesia. Hakhak tersebut adalah:

1. Hak untuk melakukan ibadah,

2. Hak untuk mendapat perawatan rohani dan jasmani,

3. Hak pendidikan,

4. Hak Pelayanan Kesehatan dan makanan yang layak,

5. Hak menyampaikan keluhan,

6. Hak memperoleh informasi,

7. Hak mendapatkan upah atas pekerjaannya,

8. Hak menerima kunjungan,

9. Hak mendapatkan remisi,

10. Hak mendapatkan kesempatan berasimilasi termasuk mengunjungi keluarga,

11. Hak untuk mendapatkan pembebasan bersyarat,

12. Hak mendapatkan cuti menjelang bebas, 
13. Serta hak-hak lain sesuai dengan peraturan yang berlaku. ${ }^{15}$

Di samping hak-hak tersebut, narapidana memiliki kewajiban-kewajiban yang harus dilaksanakan selama menjalani masa pidananya di LAPAS, sebagai berikut:

a. Wajib mengikuti secara tertib program pembinaan dan kegiatan tertentu.

b. Wajib menaati peraturan keamanan dan ketertiban di lingkungan LAPAS.

c. Mau bekerjasama dengan petugas.

Perlu diingat bahwa hak-hak tersebut tidak diperoleh secara otomatis tetapi dengan syarat atau kriteria tertentu. Sama halnya dengan pemberian remisi. Remisi diberikan karena merupakan salah satu sarana hukum yang penting dalam rangka mewujudkan tujuan sistem pemasyarakatan, selain itu remisi diberikan karena negara Indonesia menjamin kemerdekaan tiap-tiap penduduk untuk memeluk agamanya masing-masing, termasuk setiap narapidana, sehingga tidak terjadi diskriminasi dalam hal Hak Asasi Manusia. Dalam rangka pelaksanaan hak-hak narapidana, Pemerintah memberikan kesempatan kepada narapidana untuk memperbaiki diri selama menjalani hukumannya sehingga diharapkan dapat menyesali dan ketika keluar dari penjara dapat diterima kembali ke tengah-tengah kehidupan bermasyarakat.

Menurut Keppres RI No 174 Tahun 1999 yang berwenang memberikan remisi adalah Menteri Hukum dan HAM. Ini sesuai dengan Keputusan Menteri Hukum dan Perundang-Undangan RI Nomor: M.09.HN.02.01 Tahun 1999 tentang Keppres RI No 174 Tahun 1999 tentang Remisi pasal 2 yakni:

(1) Dalam hal pemberian remisi, Menteri dapat mendelegasikan pelaksanaannya kepada Kepala Kantor Wilayah.

(2) Penetapan pemberian Remisi seperti dimaksud dalam ayat (1) dilaksanakan dengan Keputusan Kepala Kantor Wilayah atas nama Menteri.

(3) Segera setelah mengeluarkan penetapan sebagaimana dimaksud dalam ayat (2), Kepala Kantor Wilayah wajib menyampaikan laporan tentang penetapan pengurangan masa pidana tersebut kepada Menteri cq. Direktur Jenderal Pemasyarakatan. ${ }^{16}$

Di Indonesia terdapat tiga jenis remisi, yaitu remisi umum, remisi khusus dan remisi tambahan. Dengan adanya remisi umum dan remisi khusus menurut Keppres RI No 174 tahun 1999, maka terpidana bisa saja dalam satu tahun dimungkinkan mendapat dua kali remisi, ini karena selain berkelakuan baik, remisi umum diberikan setiap tanggal 17 Agustus atau hari kemerdekaan negara, dan remisi khusus diberikan setiap hari besar agama yang dianut oleh terpidana. Dengan demikian, putusan hakim yang bersifat tetap dalam palaksanaannya dapat berubah dengan pemberian remisi ini, di sini perlunya adanya pengetatan pemberian remisi agar tidak menimbulkan kecemburuan dan menghindari terjadinya gesekan antar narapidana, karena jelas tidak mungkin semua narapidana akan mendapatkan remisi dua kali dalam setahun.

Selain dengan adanya kedua remisi tersebut, terdapat juga Remisi Tambahan sebagaimana diatur dalam Pasal 3 ayat (1) dimana narapidana memperoleh Remisi Tambahan apabila Narapidana yang bersangkutan selama menjalani masa pidana:

a. Berbuat jasa kepada Negara;

b. Melakukan perbuatan yang bermanfaat bagi Negara atau kemanusiaan; 
c. Melakukan perbuatan yang membantu kegiatan pembinaan di Lembaga Permasyarakatan.

Kegiatan-kegiatan kemanusiaan ataupun perbuatan yang bermanfaat bagi negara yang dilakukan di luar penjara sebaiknya dikhususkan bagi narapidana yang telah menjalani lebih dari dua pertiga masa hukumannya. Dengan masa seperti itu, memungkinkan seorang nara pidana mendapat predikat berkelakuan baik, selain berinteraksi dengan dunia luar narapidana diberi kesempatan untuk pencitraan baik bagi dirinya sehingga setelah bebas nanti dapat diterima dikehidupan masyarakat terlebih bagi narapidana kasus pembunuhan yang pada umumnya telah di cap sebagai seorang pembunuh.

Kewenangan yang diberikan kepada otoritas birokrasi memungkinkan adanya celah untuk melakukan hal-hal yang tak sepatutnya, seperti melakukan suatu kerja sama yang tidak patut atau dengan cara suap dan sogokan untuk mempermudah napi memperoleh remisi. Karena itu, perlu adanya pengawasan yang ketat dari pemegang otoritas tertinggi agar tidak terjadi pelanggaran tersebut.

\section{Klasifikasi dan Syarat-syarat Pemberian Remisi} yaitu: ${ }^{17}$

Remisi menurut KeppresRI No 174 Tahun 1999 dibagi menjadi tiga (3)

a. Remisi umum yaitu Remisi yang diberikan pada hari peringatan Proklamasi Kemerdekaan Republik Indonesia tanggal 17 Agustus.

b. Remisi khusus yaitu Remisi yang diberikan pada hari besar keagamaan yang dianut oleh Narapidana dan Anak Pidana yang bersangkutan, dengan ketentuan jika suatu agama mempunyai lebih dari satu hari besar keagamaan dalam setahun, maka yang dipilih adalah hari besar yang paling dimuliakan oleh penganut agama yang bersangkutan.

c. Remisi tambahan yaitu Remisi yang diberikan apabila Narapidana atau Anak Pidana yang bersangkutan selama menjalani pidana berbuat jasa kepada negara, melakukan perbuatan yang bermanfaat bagi negara atau kemanusiaan, atau melakukan perbuatan yang membantu kegiatan pembinaan di Lembaga Pemasyarakatan.

1. a. Besarnya remisi umum adalah:

1) 1 (satu) bulan bagi Narapidana dan Anak Pidana yang telah menjalani pidana selama 6 (enam) sampai 12 (dua belas) bulan; dan

2) 2 (dua) bulan bagi Narapidana dan Anak Pidana yang telah menjalani pidana selama 12 (dua belas) bulan atau lebih.

b. Pemberian remisi umum dilaksanakan sebagai berikut:

1) Pada tahun pertama diberikan remisi sebagaimana dimaksud dalam angka 1 di atas;

2) Pada tahun kedua diberikan remisi 3 (bulan);

3) Pada tahun ketiga diberikan remisi 4 (empat) bulan;

4) Pada tahun keempat dan kelima masing-masing diberikan remisi 5 (lima) bulan; dan 
5) Pada tahun keenam dan seterusnya diberikan remisi 6 (enam) setiap tahun c. Syarat mendapatkan remisi umum adalah:

1) Warga Binaan Pemasyarakatan tidak sedang menjalani Cuti Menjelang Bebas

2) Warga Binaan Pemasyarakatan tidak sedang menjalani pidana pengganti denda.

3) Warga Binaan Pemasyarakatan tidak sedang menjalani hukuman mati atau seumur hidup.

4) Sudah menjalani lebih dari 6 (enam) bulan.

5) Tidak dikenakan hukuman disiplin.

2. a. Besarnya remisi khusus adalah:

1) 15 (lima belas) hari bagi Narapidana dan Anak Pidana yang telah menjalani pidana selama 6 (enam) sampai 12 (dua belas) bulan; dan

2) 1 (satu) bulan bagi Narapidana dan Anak Pidana yang telah menjalani pidana selama 12 (dua belas) bulan atau lebih.

b. Pemberian remisi khusus dilaksanakan sebagai berikut:

1) Pada tahun pertama diberikan remisi sebagaimana dimaksudkan dalam angka 1 tersebut di atas;

Pada tahun kedua dan ketiga masing-masing diberikan remisi 1(satu) bulan;

2) Pada tahun keempat dan kelima masing-masing diberikanremisi 1 (satu) bulan 15 (lima belas) hari; dan

3) Pada tahun keenam dan seterusnya remisi 2 (dua) bulan setiap tahun.

c. Syarat mendapatkan remisi khusus adalah sebagai berikut:

1) Waga Binaan Pemasyarakatan tidak sedang menjalani Cuti Menjelang Bebas.

2) Warga Binaan Pemasyarakatan tidak sedang menjalani pidana pengganti denda.

3) Warga Binaan Pemasyarakatan tidak sedang menjalani hukuman mati atau seumur hidup.

4) Sudah menjalani pidana lebih dari 6 (enam) bulan.

5) Tidak dikenakan hukuman disiplin.

3. a. Besarnya remisi tambahan adalah:

1) $1 / 2$ (satu perdua) dari remisi umum yang diperoleh pada tahun yang bersangkutan bagi Narapidana dan Anak Pidana yang berbuat jasa kepada Negara atau melakukan perbuatan yang bermanfaat bagi Negara atau kemanusiaan; dan

2) $11 / 3$ (satu pertiga) dari remisi umum yang diperoleh pada tahun yang bersangkutan bagi Narapidana dan Anak Pidana yang telah melakukan perbuatan yang membantu kegiatan Pembinaan di Lapas sebagai pemuka.

b. Remisi tambahan tidak diberikan kepada Narapidana dan Anak Pidana, yang:

1) Dipidana kurang dari 6 (enam) bulan;

2) Dikenakan hukuman disiplin dan didaftar pada buku pelanggaran tata tertib; 
3) Lapas dalam kurun waktu yang diperhitungkan pada pemberian remisi;

4) Sedang menjalani Cuti Menjelang Bebas; atau

5) Dijatuhi pidana kurungan sebagai pengganti denda.

c. Syarat mendapatkan remisi tambahan adalah sebagai berikut:

1) Warga Binaan Pemasyarakatan tidak sedang menjalani Cuti Menjelang Bebas.

2) Warga Binaan Pemasyarakatan tidak sedang menjalani pidana pengganti denda.

3) Warga Binaan Pemasyarakatan tidak sedang menjalani hukuman mati atau seumur hidup.

4) Sudah menjalani pidana lebih dari 6 (enam) bulan.

5) Tidak dikenakan hukuman disiplin.

Melihat kriteria yang harus dipenuhi oleh setiap narapidana ataupun anak pidana maka kriteria yang paling jelas yaitu Narapidana ataupun Anak Pidana tersebut telah menjalani hukuman minimal enam bulan. Dengan demikian bagi Narapidana yang dijatuhi hukuman dibawah enam bulan tentu tidak akan pernah mendapatkan remisi. Tentu jika dilihat dari segi keadilan dirasa kurang karena sama-sama menjalani hukuman tetapi tidak mendapat remisi. Sehingga menurut penyusun seharusnya perlu adanya peraturan khusus bagi Narapidana maupun Anak Pidana yang mendapat hukuman dibawah enam bulan seperti halnya tidak diletakkan di dalam penjara tetapi diletakkan di tempat yang memberikan pelatihan keterampilan seperti halnya balai latihan kerja tetapi tetap harus mendapat pengawasan dari pihak yang berwenang, adanya batas minimum hukuman bagi Narapidana atau Anak Pidana untuk mendapatkan remisi yaitu sudah menjalani hukuman minimal enam bulan penjara. Jadi bagi Narapidana dan Anak Pidana yang mendapat hukuman dibawah enam bulan tidak akan mendapatkan remisi. Di dalam Keppres RI No 174 Tahun 1999 tidak mengkhususkan pemberian remisi kepada tindak pidana pembunuhan semata, tetapi pasal-pasal yang terkandung dalam Keppres ini menjelaskan remisi untuk semua tindak pidana umum termasuk di dalamnya adalah tindak pidana pembunuhan.

Kitab Undang-Undang Hukum Pidana (KUHP) khususnya pasal-pasal tentang pembunuhan, sanksi yang diancamkan minimal empat tahun (pasal 345 dan 346 KUHP) dan maksimal hukuman mati atau seumur hidup (pasal 339 dan 340 KUHP) sehingga dengan demikian sudah jelas bahwa setiap Narapidana atau Anak Pidana yang melakukan tindak pidana pembunuhan pasti mendapat remisi jika dilihat dari lamanya hukuman yang dijalani yakni lebih dari enam bulan penjara asalkan ia berkelakuan baik selama menjalani hukumannya. Tetapi, di dalam Keputusan Menteri Hukum Dan Perundang-undangan Republik Indonesia Nomor: M.09.Hn.02.01 Tahun 1999 tentang Pelaksanaan Keputusan Presiden Republik Indonesia Nomor: 174 tahun 1999 Tentang Remisi pada pasal 1 ayat 5 yang berbunyi: "Narapidana yang berkelakuan baik ialah Narapidana yang mentaati peraturan yang berlaku dan tidak dikenakan tindakan disiplin yang dicatat dalam buku register $\mathrm{F}$ selama kurun waktu yang diperhitungkan untuk pemberian remisi." ${ }^{18}$ Menurut penyusun perbuatan baik itu mempunyai makna yang luas, karena bisa saja perbuatan baik itu ditafsirkan berbuat 
baik kepada kalapas atau sipir-sipir penjara yang tiap hari bersinggungan sehingga muncul celah untuk melakukan hal-hal yang curang seperti penyuapan kepada petugas agar ia mendapatkan remisi. Tentu ini bukanlah perbuatan yang bisa disebut berkelakuan baik untuk benar-benar mendapat remisi. Sehingga perlu adanya spesifikasi berkelakuan baik dan jika perlu bagi terpidana yang tertangkap melakukan kerja sama dengan petugas harus diberi sanksi berupa penambahan masa hukuman sehingga dia benar-benar jera. Termasuk sanksi kepada aparat yang bersangkutan bila perlu diberhentikan secara tidak hormat karena telah membantu seseorang yang telah bersalah dan sedang menjalani hukuman.

\section{Analisis Hukum Pidana Islam}

Pengampunan dalam hokum pidana Islam merupakan salah satu faktor pengurangan hukuman (remisi), baik diberikan oleh korban atau walinya atau penguasa Negara. Pengampunan atau syafaat juga diartikan sebagai keringanan atau dihapuskannya dosa bagi orang-orang yang telah melakukan kesalahan di dunia juga syafaat berarti keluarnya orang-orang yang berdosa besar dari neraka suatu saat kelak. Pengaruh pengampunan hanya berlaku pada hukuman atau jarimah kisas, diat, takzir. Hukuman lain bagi jarimah kisas diat seperti kifarat tidak bisa dimaafkan olehnya.Sehingga pengampunannya tidak dihapuskan oleh hak penguasa negara untuk menjatuhkan hukuman takzir. ${ }^{19}$

Remisi diberikan karena Narapidana dinilai berbuat baik dan menyesali perbuatannya, ini juga sejalan dengan tujuan syara' yaitu menghindarkan umat manusia dari kerusakan dan keburukan karena selama menjalankan hukuman di lembaga pemasyarakatan Narapidana diberi bimbingan maupun pelatihan dan lainlain dengan maksud agar ia tidak mengulangi dan juga mau menyesali perbuatannya yang telah dilakukan sebelumya sehingga muncul rasa tobat, ini iuga menandakan adanya perlindungan jiwa sebagai salah satu tujuan penetapan hukum yakni memelihara agama, jiwa, akal, keturunan dan harta. Selain itu penyusun juga belum menemukan hukum syara' yang menolak tentang penerapan remisi ini.

Perlu dicermati mengenai subjek pemberi ampunan yaitu Presiden, dan terpidana harus mengajukan sendiri, lain halnya dengan remisi yang mana merupakan pengurangan masa menjalani pidana yang diberikan kepada Narapidana dan Anak Pidana yang memenuhi syarat-syarat yang ditentukan dalam peraturan perundangundangan dengan pengawasan Kalapas dan dengan persetujuan Menteri Hukum dan HAM. Dengan kata lain, remisi ini diberikan karena terpidana dinilai telah melakukan perbuatan yang baik selama menjalani hukumannya dan menyesali perbuatan yang dilakukannya. Remisi yang diberikan kepada pelaku tindak pidana pembunuhan maka di dalam al-Qur'an pun telah dijelaskan tentang anjuran untuk memberikan ampunan kepada pelaku tindak pidana pembunuhan yang diancam dengan hukuman kisas, hal ini sesuai dengan firman Alla SWT dalam QS. al-Baqarah/2: 178 dan QS. alMaidah/4: 45 yang telah dijelaskan dalam bab sebelumya.

Selain itu demi mengimplementasikan bahwa pelaku benar-benar menyesali maka Allah swt. menyuruh untuk bertobat bagi orang-orang yang telah melakukan kezaliman, artinya orang-orang yang melakukan perbuatan yang dilarang oleh syariat 
agama, karena Allah swt. mau memberikan ampunan kepada orang-orang yang benarbenar menyadari dan menyesali atas apa yang mereka perbuat. Hal ini sesuai firman Allah swt. dalam QS Al Furqaan/ 25: 70

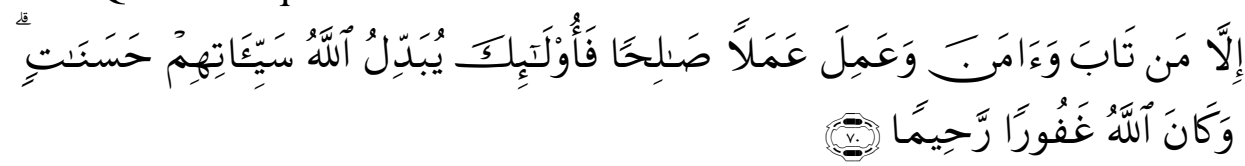

Terjemahannya:

"Kecuali orang-orang yang bertaubat, beriman dan mengerjakan amal saleh; Maka itu kejahatan mereka diganti Allah dengan kebajikan. dan adalah Allah Maha Pengampun lagi Maha Penyayang.,"20

Islam mewajibkan keadilan dan mengharamkan kedzaliman. Ajaran-ajaran dan nilainya yang luhur dalam bentuk cinta kasih, tolong menolong, keutamaan, pengorbanan kepentingan sendiri dapat menciptkan kelembutan hidup dan mendekatkan hati serta mempersaudarakan sesama manusia. Kemudian Islam menghargai akal pikiran manusia serta menjadikan keduanya sebagai sarana untuk saling memahami dan mengerti. Islam menitik beratkan kepada perdamaian antara sesama manusia, saling menghormati saling menghargai dan saling memaafkan, sebab yang disebut benar yang mutlak itu hanya Allah yang punya, manusia hanya kebenaran saja, dan benar menurut sendiri belum tentu benar menurut pandangan orang lain. Oleh karena itu, menurut pandangan hukum yang berlaku di masyarakat dan menurut hukum sudah ditetapkan oleh Negara. Apabila yang benar dan yang salah belum ditetapkan oleh Undang-undang maka kebenaran dan kesalahan masih bersifat subyektif, oleh karenanya Undang-undang dan hukum masyarakat perlu mengaturnya, demi kebaikan dan ketentraman manusia bermasyarakat dan bernegara.

Pemaafan atau perdamaian dalam pandangan hukum Islam, merupakan hukuman juga dan pelaku tindak pidana sebelumnya harus minta maaf dan menyesali atas perbuatannya yang telah merugikan korban. Hal ini memberikan pelajaran bahwa pelaku tindak pidana harus mengakui segala kesalahanya terlebih dahulu, sementara untuk mengakui kesalahan adalah suatu yang berat, sebab pada dasarnya manusia selalu merasa benar terus apa yang dilakukannya, padahal hukum mengaturnya dan menyatakan bahwa perbuatannya salah. Oleh karena itu, untuk mengakui bahwa perbuatan yang dilakukannya itu adalah salah memang berat apalagi yang dimintai maafnya adalah bukan siapa-siapa dan tidak memiliki apa-apa, dalam pandangan-Nya semuanya sama, didepan Yang Maha Kuasa sama-sama mahluk yang diciptakan-Nya, disini ada pelajaran kejujuran, dan lapang dada mengakui atas kesalahan, sedangkan korban atau keluarganya untuk memaafkan orang yang sudah menyakitinya itu pun berat, ini pelajaran untuk berlapang dada menerima kenyataan dan ujian hidupnya. Pemaafan diberikan sesudah terjadinya perdamaian dan kebersihan hati mau saling memaafkan dan melaksanakan hak dan kewajiban masingmasing pihak. Pemberian maaf oleh korban, atau wali dianjurkan oleh al-Qur'an, dan akan diberi pahala di akhirat serta keridhoan Tuhan dan syariat Islam memandang pengampunan/pemaafan tersebut sebagai rahmat dari Tuhan atas manusia 
Hukum pidana Islam menjunjung nilai-nilai kemanusian yang universal dan memberikan rasa keadilan yang seimbang dengan menempatkan keluarga korban sebagai unsur penentu dalam menjatuhkan hukuman pidana mati terhadap pelaku pidana pembunuhan. Penjatuhan hukuman mati atau dibebaskan dari hukuman mati didasarkan pada etekad baik keluarga korban.

Hukuman bagi pelaku pembunuhan dalam hukum pidana Islam terbagi dalam tiga jenis, yaitu hukuman pokok, hukuman pengganti, dan hukuman tambahan. Hukuman pokok pembunuhan adalah kisas dan bila dimaafkan oleh wali korban maka hukuman penggantinya adalah diat. Jika sanksi kisas dan diat dimaafkan maka hukuman penggantinya adalah takzir. Hukuman tambahan bagi jarimah ini adalah terhalangnya hak atas warisan dan wasiat. ${ }^{21}$

Keppres RI No 174 tahun 1999 terutama dalam pasal 1 diatur bahwa "setiap narapidana dan anak pidana yang menjalani pidana penjara sementara dan pidana kurungan dapat diberikan remisi apabila yang bersangkutan berkelakuan baik selama menjalani pidana" Sebagaimana yang telah dikemukakan oleh al-Ghazali, bahwa orang yang bertaubat dikatakan sempurna bila ia tidak hanya menyesali perbuatannya saja, tetapi ia harus mengikuti dan mengganti perbuatan tersebut dengan perbuatan baik. $^{22}$ Kriteria syarat tersebut secara umum sejalan dan erat hubungannya dengan salah satu prinsip hukuman dalam hukum pidana Islam, dimana hukuman adalah sebagai upaya pencegahan, media mendidik dan pengajaran, upaya menimbulkan efek jera.

Tabel

Pemberian Remisi

Dalam Hukum Nasional dan Hukum Islam

\begin{tabular}{|c|c|}
\hline $\begin{array}{c}\text { Pemberian Remisi dalam Hukum } \\
\text { Nasional }\end{array}$ & $\begin{array}{c}\text { Pemberian Remisi dalam } \\
\text { Hukum Islam }\end{array}$ \\
\hline $\begin{array}{c}\text { Pelaku Lebih Dahulu Menjalani } \\
\text { Hukuman }\end{array}$ & $\begin{array}{c}\text { Pelaku Tidak Menjalani } \\
\text { Hukuman }\end{array}$ \\
\hline $\begin{array}{c}\text { Setelah Memenuhi Syarat-Syarat } \\
\text { yang Telah Ditentukan Dalam } \\
\text { PP }\end{array}$ & $\begin{array}{c}\text { Setelah Bertaubat dengan } \\
\text { Sungguh-sungguh }\end{array}$ \\
\hline $\begin{array}{c}\text { Perkara Sudah Diputus Oleh } \\
\text { Hakim }\end{array}$ & $\begin{array}{c}\text { Perkara Sebelum/Sesudah } \\
\text { Sampai Kepada Hakim/Ulil } \\
\text { Amri }\end{array}$ \\
\hline $\begin{array}{c}\text { Diberikan Oleh Menteri Hukum } \\
\text { dan Ham }\end{array}$ & $\begin{array}{c}\text { Diberikan Oleh Hakim/Ulil } \\
\text { Amri dan Atau Juga Pihak } \\
\text { Korban }\end{array}$ \\
\hline
\end{tabular}

Dari keterangan-keterangan di atas, tampak bahwa syarat atau kriteria pokok dari pemberian pengurangan hukuman (remisi) di Indonesia (dalam Hukum Pidana Nasional) pada dasarnya tidak terlepas dari prinsip-prinsip pokok hukum pidana 
dalam Islam. Hal ini dapat kita cermati dari kriteria atau syarat yang harus di penuhi oleh pelaku, yakni, berbuat baik selama di dalam tahanan, menyesalinya dan berniat untuk tidak mengulanginya lagi.

\section{Kesimpulan}

Hak atas remisi di Indonesia sebagaimana yang telah diatur dalam Keputusan Presiden Republik Indonesia Nomor 174 Tahun 1999 tentang remisi adalah diperuntukkan bagi narapidana yang memenuhi syarat-syarat menuju kebaikan dalam arti bertaubat. Dalam ajaran Islam kelakuan baik merupakan manifestasi dari sifat dan wujud penyempurnaan dri rasa penyesalan seseorang atas perbuatan masa lalunya atau perbuatan jahat yang telah ia lakukan, dan juga sebagai wujud dari penyempurnaan taubat seseorang, dan kriteria yang diperuntukkan bagi narapidana yang mendapatkan remisi memberi pandangan bahwa narapidana tersebut ada rasa penyesalan dan indikasi bertaubat. Kriteria tersebut juga secara umum sejalan dan erat hubungannya dengan salah satu prinsip hukuman dalam pidana Islam, dimana hukuman adalah sebagai pencegahan (ar-rad-u waz-zajru) media pendidik dan pengajaran (al-Islam al-Tahzib)

Pelaksanaan remisi di Indonesia menurut Keputusan Presiden Republik Indonesia Nomor 174 Tahun 1999 tentang Remisi, pada dasarnya tidak lepas dari prinsip-prinsip pokok hukum pidana Islam. Akan tetapi hal ini terdapat perbedaan, yakni dalam hukum pidana Islam pengurangan hukuman dapat diberikan sebelum atau sesudah putusan hakim (vonis).

Konsep hukuman dalam hukum pidana Islam yang berpangkal kepada kemaslahatan dan media pendidikan serta pengajaran. Demikian pula dengan masalah pengampunan, sekiranya pengampunan tersebut berfungsi sebagai upaya menghargai hak-hak Narapidana, maka di sinilah justru mencakup tujuan syari'at yang paling utama adalah prinsip kemaslahatan. Sehingga upaya menjaga ketertiban dan ketentraman dapat tercapai dan tidak terabaikan. Prinsip kemaslahatan inilah yang menjadi tujuan utama adanya remisi di Indonesia. Dan hal tersebut sejalan dengan pokok-pokok ajaran syari'at Islam, dimana segala peraturan-peraturan yang disyari'atkan pada Islam hakekatnya bermuara pada prinsip kemaslahatan tersebut. Adanya peraturan yang berupa perintah dan larangan dalam syari'at Islam dimaksudkan agar kemaslahataan hidup manusia menjadi terjaga dan terlindungi, terutama kemaslahatan di dunia dan akhirat.

\section{Saran-saran}

1. Penentukan kriteria berkelakuan baik seyogyanya dilihat secara menyeluruh, dan perlu pemantauan terhadap narapidana yang mendapatkan hak remisi ketika sudah berada di tengah-tengah masyarakat agar dapat secara konsisten merubah segala perbuatannya ke jalan yang benar.

2. Perlu adanya penyederhanaan prosedur dalam proses pengajuan remisi tanpa mengurangi maksud dan tujuan dari remisi itu sendiri. Lembaga pemasyarakatan sebenarnya mempunyai tujuan yang baik tetapi akan lebih baik lagi jika aparat yang berada didalamnya mempunyai dedikasi untuk benar- 
benar menegakkan dan memberikan pembinaan yang baik pula sehingga tidak ada lagi narapidana yang bisa keluar jalan-jalan dengan cara menyogok aparat terkait.

\section{Endnotes:}

${ }^{1}$ Moeljatno, Perbuatan Pidana dan Pertanggungjawaban dalam Hukum Pidana (Jakarta: Bina Aksara, 2003), h. 6.

${ }^{2}$ Moeljatno, Asas-asas Hukum Pidana (Jakarta: Bina Aksara,2004), h. 167.

${ }^{3}$ Zainudin Ali, Hukum Pidana Islam (Jakarta: Sinar Grafika, 2009), h. 1.

${ }^{4}$ Moeljatno, Perbuatan Pidana dan Pertanggungjawaban dalam Hukum Pidana (Jakarta: Bina Aksara, 2003), h. 6.

${ }^{5}$ Andi Hamzah, KUHP dan KUHAP (Jakarta: Rineka Cipta, 2006), h. 134.

h.186.

${ }^{6}$ Abdoel Djamali, Pengantar Hukum Indonesia (Bandung: CV, Mandar Maju, 1997),

${ }^{7}$ Zainudin Ali, Hukum Pidana Islam, h.11.

${ }^{8}$ Muhammad Amin Suma, Pidana Islam Di Indonesia Peluang, Prospek, Dan Tantangan (Jakarta: Pustaka Firdaus, 2001), h. 88.

${ }^{9}$ Departemen Agama RI., Al-Qur'an dan Terjemahnya (Jakarta: LUBUK AGUNG BANDUNG, 1989), h. 43.

${ }^{10}$ Ahmad Wardi Muslich, Pengantar Dan Asas Hukum Pidana Islam Fiqh Jinayah (Jakarta: Sinar Grafika, 2006), h. 173.

${ }^{11}$ Departemen Agama RI, Al-Qur'an dan Terjemahnya, h. 43.

$12{ }^{12}$ Abdoel Djamali, Pengantar Hukum Indonesia, h. 188.

${ }^{13}$ Andi Hamzah, Kamus Hukum (Jakarta: Ghalia Indonesia, 1986), h. 503.

${ }^{14}$ Keppres RI No 174 tahun 1999 pasal 1

${ }^{15}$ Hadi Setia Tunggal, Undang-undang Pemasyarakatan, (Jakarta: Haevarindo, 2000), h.

$7-8$.

\footnotetext{
${ }^{16}$ Keputusan Menteri Hukum No : M.09.HN.02.01 Tahun 1999.

${ }^{17}$ Keputusan Presiden RI No 174 Tahun 1999
} 


\footnotetext{
${ }^{18}$ Keputusan Menteri Hukum Dan Perundang-Undangan Republik Indonesia Nomor : M.09.Hn.02.01 Tahun 1999 Tentang Pelaksanaan Keputusan Presiden Republik Indonesia Nomor : 174 Tahun 1999 Tentang Remisi

${ }^{19}$ Ahmad Hanafi, Asas-asas Hukum Pidana Islam (Jakarta:Sinar Grafika, 1967), h. 348.

${ }^{20}$ Departemen Agama RI., al-Qur'an dan Terjemahnya., h. 569.

${ }^{21}$ Topo Santoso, Membumikan Hukum Pidana Islam: Penegakan Syariat Dalam Wacana
} Dan Agenda, (Jakarta: Gema Insani Press, 2003), h. 37.

${ }^{22}$ Al-Ghazali, Taubat, Sabar dan Syukur, alih bahasa Nur Hikmah dan RHA Suminta (Jakarta: Tinta Mas, 1983), h. 22.

\section{DAFTAR PUSTAKA}

Al Audah, Abdul Qadir. Ensiklopedia Hukum Pidana Islam/Editor, diterjemahkan oleh Muhammad Ahsin Sakho Dari "At Tasri Al Fiqh Al Jina 'i”. Jakarta: PT Kharisma Ilmu. 2008.

Al- Zuhaili, Wahbah. Al-Qur'an al-Karim, Bunyatuh al-Tasyri'iyyah wa Khasa'isuh al-Hadariyyah. Terj. Mohamad Luqman Hakiem dan Mohammad Fuad Hariri, Al-Qur'an: Paradigma Hukum dan Peradaban. Surabaya: Risalah Gusti. 1996.

Al-Mawardi, Abu Al-Hasan. Al-Ahkam As-Sulthaniyah. Mesir: Mustafa Al-Babyi AlHalaby, cet. Ke-3. 1975.

Ali, Zainudin. Hukum Pidana Islam. Jakarta: Sinar Grafika. 2009.

Ali, Zainudin. Hukum Islam, Pengantar Ilmu Hukum Islam Di Indonesia. Jakarta: Sinar Grafika. 2006.

Kementerian Agama RI.Al Qur'an Dan Terjemahannya. Semarang: Cv Asy Syifa'. 2000.

Djamali, Abdul, Pengantar Hukum Indonesia. Bandung: Cv Mandar Maju. 1997.

Djazuli, Fiqh Jinayah; Upaya Menanggulangi kejahatan dalam Islam. Jakarta: Raja GrafindoPersada. 1997. 
Doi, A Rahman I. Syariah the Islamic Law. Terj. Zainuddin dan Rusydi Sulaiman, Hudud dan Kewarisan (syariah II). Cet. I; Jakarta: PT RjaGrafindo Persada. 1996.

Erwin, Rudy T. dan J.T. Prasetyo. Himpunan Undang-undang dan Peraturanperaturan Hukum Pidana. Jilid I. Jakarta: Aksara Baru. 1980.

Hadikusuma. Hilman, Bahasa Hukum Indonesia. Bandung: Alumni. 1992.

Hamzah. Andi. Asas-Asas Hukum Pidana. Jakarta; Rineka Cipta. 1991.

Hamzah. Kamus Hukum. Jakarta: Ghalia Inonesia. 1986.

Hamzah. KUHP Dan KUHAP. Jakarta; Rineka Cipta. 2006.

Hamzah. Delik-Delik Tertentu (Special Delicten) Di Dalam KUHP. Jakarta: Sinar Grafika. 2010.

Halim, Andreas. Kamus Lengkap 10 Milyar. Surabaya: Sulita Jaya. 1999.

Hanafi, Ahmad. Asas-Asas Hukum Pidana Islam. Jakarta:PT Bulan Bintang. 1993.

Kasdi, Abdurrahman dan Umma Farida. Tafsir Ayat-Ayat Yaa Ayyuhal-Ladziina Аатапии 1. Jakarta: Pustaka Al Kautsar. 2005.

Keputusan Presiden Republik Indonesia No 174 Tahun 1999 tentang Remisi.

Keputusan Presiden republik Indonesia Peraturan Pemerintah RI No 32 tahun 1999 tentang syarat dan tata cara pelaksanaan Hak Warga Binaan.

Keputusan Menteri Hukum Dan Perundang-Undangan Republik Indonesia Nomor: M.09.Hn.02.01 Tahun 1999 Tentang Pelaksanaan Keputusan Presiden Republik Indonesia Nomor: 174 Tahun 1999 Tentang Remisi.

Lamintang, P.A.F. Delik-delik Khusus. cet. 1. Bandung: Bina Cipta. 1986.

Lamintang, P.A.F. Kejahatan Terhadap Nyawa, Tubuh, \& Kesehatan. Jakarta: Sinar Grafika. 2010.

Lamintang, P.A.F. Hukum Penitensier Indonesia. Bandung: Armico. 1988.

Marpaung, Leden. Asas, Teori, Praktek, Hukum Pidana. Jakarta: Sinar Grafika. 2005.

Marpaung, Leden. Tindak Pidana Terhadap Nyawa dan Tubuh. Jakarta: Grafika.2007.

Marpaung, Leden. Kitab Undang-Undang Hukum Pidana. Jakarta; PT Bumi Aksara. 2007.

Moeljatno. Perbuatan Pidana dan Pertanggungjawaban dalam Hukum Pidana. Jakarta: Bina Aksara. 2003.

Moeljatno. Asas-asas Hukum Pidana. Jakarta: Bina Aksara. 2004. 
Munawir. Ahmad Warson. Al-Munawwir, cet. Ke-1. Yogyakarta: Pustaka Progresif. 1992.

Muslich, Ahmad Wardi. Hukum Pidana Islam. Jakarta: Sinar Grafika. 2005.

Muslich, Ahmad Wardi. Pengantar Dan Asas Hukum Pidana Islam Fiqh Jinayah. Jakarta: Sinar Grafika. 2006.

Priyatno, Dwidja. Sistem Pelaksanaan Pidana Penjara Di Indonesia. Bandung: Refika Aditama. 2006.

Rosyada, Dede. Hukum Islam dan Pranata Sosial. Jakarta: Lembaga Studi Islam dan Kemasyarakatan. 1992.

Sabiq, Sayyid (ed.), Fiqih Sunah, Diterjemahkan Oleh Nor Hasanuddin Dari "Fiqhus Sunah". Jakarta: Pena Pundi Aksara. 2006.

Santoso, Topo, Membumikan Hukum Pidana Islam: Penegakan Syariat Dalam Wacana Dan Agenda. Jakarta: Gema Insani Press. 2003.

Shihab, M. Quraishi, Tafsir Al Misbah, Pesan, Kesan Dan Keserasian Al Quran. Jakarta: Lentera Hati. 2002.

Soedarsono. Kamus Hukum. Jakarta: Rhineka Cipta. 1992.

Soedarsono. Pokok-Pokok Hukum Islam. Jakarta; PT. Rineka Cipta. 1993.

Suma, Muhammad Amin. Pidana Islam di Indonesia Peluang, Prospek, dan Tantangan. Jakarta: Pustaka Firdaus. 2001.

Suparni, Ninik. Eksistensi Pidana Denda dalam Pidana dan Pemidanaan, ed. I. Jakarta: Sinar Grafika. 2007.

Tim Penyusun Kamus Pusat Bahasa, Kamus Besar Bahasa Indonesia. Jakarta: Balai Pustaka. 2005. 